\section{B A Institute of \\ YK Business Administration \\ TK \\ Karachi \\ Leadership and Ideas for Tomorrow}

Business Review

Volume 2 Issue 2 July-December 2007

7-1-2007

\title{
The drivers and barriers to customer value creation: Issues and prespectives in the marble sector SMEs of North-West Frontier Province, Pakistan
}

Muhammad Noman

Institute of Management Sciences (IMSciences) Peshawar, Pakistan

Follow this and additional works at: https://ir.iba.edu.pk/businessreview

Part of the Business Intelligence Commons, Entrepreneurial and Small Business Operations Commons, International Business Commons, Mining Engineering Commons, and the Risk Analysis Commons

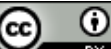

This work is licensed under a Creative Commons Attribution 4.0 International License.

\section{Recommended Citation}

Noman, M. (2007). The drivers and barriers to customer value creation: Issues and prespectives in the marble sector SMEs of North-West Frontier Province, Pakistan. Business Review, 2(2), 88-103. Retrieved from https://doi.org/10.54784/1990-6587.1391

This article is brought to you by iRepository for open access under the Creative Commons Attribution 4.0 License and is available at https://ir.iba.edu.pk/businessreview/vol2/iss2/6. For more information, please contact irepository@iba.edu.pk. 


\title{
ARTICLE
}

\section{The Drivers and Barriers to Customer Value Creation:}

\section{Issues and Perspectives in the Marble Sector SMEs of North-West Frontier Province, PAKISTAN}

\author{
Muhammad Nouman \\ Institute of Management Sciences (IMSciences) Peshawar, Pakistan
}

\begin{abstract}
The concept of value and, more specifically, customer value is of increasing interest to both academics and practitioners. Many see it as the next source of competitive advantage. Like other regions of the country, the North-West Frontier Province of Pakistan has a presence of SMEs in many sectors. A major one amongst these is the marble sector; characterized by two sub-sectors, marble mining and marble processing. A review of various studies in the marbte sector reveals that about 70 percent of marble reserves in Pakistan are being wasted due to poor mining and processing techniques. The situation is further aggravated by a lack of sound marketing strategies that are focused on value creation that enable these SMEs to enhance competitiveness and achieve greater profitability especially in the international markets. This paper, which is part of the preliminary work for PhD research being carried out by the author at the University of Southampton, UK, tries to examine some of the issues and perspectives regarding customer value creation and relates these concepts to the marble sector of N.W.F.P. The literature reviewed for this purpose lays emphasis on the concept of value from the dimension of employees and processes. It also highlights some of the drivers and barriers to value creation. By identifying some of the issues and perspectives to customer value creation, this paper would be a first step towards enhancing the competitiveness of Pakistan's marble industry especially in the international market.
\end{abstract}

\section{INTRODUCTION}

The purpose of any business is to create value for customers, employees, and investors, as the interests of these three groups are inextricably linked. Therefore, sustainable value cannot be created for one group unless it is created for all of them. The first focus should be on creating value for the customer, but this cannot be achieved unless the right employees are selected, developed, and rewarded, and investors receive consistently attractive returns (Batjargal, 2000). What does value creation mean? For the customer, it involves making products and 
providing services that customers find consistently useful. In today's business environment, such value creation is based typically on product and process innovation and on understanding unique customer needs with ever increasing speed and precision. However, companies can innovate and deliver outstanding service only if they tap on the commitment, energy, and imagination of their employees. Value must therefore be created for these employees in order to motivate and encourage them. Value for employees includes being treated respectfully and being involved in the decision making process. Employees also value meaningful work, compensation incentives, and continued training and development. Creating value for investors means delivering high returns consistently on their capital. This generally requires both strong revenue growth and attractive profit margins, which in turn, can be achieved only if a company delivers sustained value for its customers. As such, value creation plays a vital role in sustaining a company's competitive advantage.

Since partition of the Sub-continent in 1947, Pakistan has been trying to enter into the comity of developed nations. Despite the efforts to achieve economic growth it has not been very successful especially at the micro level. The improvements were usually achieved through macro level policy interventions and external aid by donor countries. That is why after more than half a century of its independence the country is still facing unemployment and an increasing poverty level (Niazi, 2005).

Keeping in view the strategies adopted by countries of the region like China, Malaysia and South Korea, it is quite obvious that a major cause of their sustained development has been introduction of an entrepreneurial culture at the grass roots level, and development of a feasible environment for establishment of Small and Medium-sized Enterprises (SMEs). These micro-level developments have provided a sustainable base and have been further strengthened by the supportive macroeconomic policies.

This brings us to a very important question: why a country like Pakistan, with $99 \%$ of the establishments characterized as Micro, Small and Medium Enterprises (MSMEs) and contributing 30\% to the Gross Domestic Product, failed to replicate the success of other countries? Research studies carried out by various organizations suggest some plausible causes including;

- Output growth rate of SME sector is lagging behind the Large Scale sector as against common perception.

- Gross Capital Formation rates suggest that SME sector is suffering from inefficiencies.

- The contribution to value added of dominating sub-sectors in Large Scale has increased but for SMEs has remained stagnant.

- Over the past few decades competitiveness of our SME sector has declined. 
- The existing and potential entrepreneurs in the country lack the guidance, knowledge and skills to start up and manage an enterprise of their own.

- The contribution of institutes of higher learning in imparting the much needed knowledge and skills is extremely limited ${ }^{1}$.

One recommendation of the Task Force for SME Policy Development, formed by the Government of Pakistan, is that in order to overcome these problems entrepreneurship development programs need to be initiated at various institutes of higher learning all across Pakistan. For this purpose, Institute of Management Sciences, Peshawar, Pakistan signed a Memorandum of Understanding with Small and Medium Enterprise Development Authority (SMEDA), Government of Pakistan for establishment of Entrepreneurship Development Center (EDC). The EDC is involved in primary and need-based research and training projects to generate updated knowledge and information for the SME sector and provide it with skilled human resource.

In Pakistan, many sectors have a presence of a large number of SMEs. A major one amongst these present in the North-West Frontier Province (N-WFP) of the country is the Marble and Granite Sector. Within the Marble sector there are two sub-sectors, Marble Mining and Marble Processing.

Marble is a crystalline, compact variety of metamorphosed limestone, consisting primarily of calcite $(\mathrm{CaCO} 3)$, dolomite $(\mathrm{CaMg}(\mathrm{CO} 3) 6)$ or a combination of both. Extensive deposits are located in Italy, India, Pakistan, Greece, Brazil, China, Afghanistan, Turkey, Great Britain and the United States. Commercially, the term marble is extended to include any rock composed of calcium carbonate that takes polish including ordinary limestone (Iqbal, 2005).

Marble is the sixth largest mineral extracted; the others being coal, rock salt, limestone and china clay. Since 1990, mining \& quarrying have consistently contributed $0.5 \%$ to the GDP. Pakistan's production for the year 2003-04 was 598,000 tons, with less than $10 \%$ exported $(0.03 \%$ of the world trade).

The United States Agency for International Development (USAID), under its Strategic Working Group (SWOG), is working on various interventions in the marble sector to improve its productivity, efficiency and cluster cooperation. A major part of this intervention is the 'Dimensional Stone Strategy' meant to develop Model Quarries to overcome heavy losses in the industry due to poor mining techniques. SWOG is also working on developing feasible Business Plans for the

\footnotetext{
12005 , 'Consultative Workshop on SME Policy Development', sponsored by Small and Medium Enterprise Development Authority, Government of Pakistan, at Pearl Continental Hotel, Peshawar
} 
marble-processing sector. The European Commission under its project, Pakistan Financial Services Sector Reform Program (PFSSRP), completed a research study in 2006-07 titled 'Cluster Mapping of the Marble Sector in North-West Frontier Province.'

However, a careful review of the projects and studies carried out for the uplift of the Marble Industry in Pakistan reveals a lack of developing sound marketing strategies that are focused on value creation and enable a firm to enhance competitiveness and achieve greater profitability. The issues of how value can be created from the dimension of employees and processes; identification of the drivers and barriers of value in the marble sector; and determination of the impact of these factors on the industry need to be further explored.

\section{LITERATURE REVIEW VALUE CREATION AND COMPETITION}

MacDonald and Ryall (2001) provide a definition for value creation, competition, and value appropriation, and in their research they show that (1) there is a minimal level of value creation that is required if competition is to allow a firm to appropriate value; (2) there is a higher level of value creation guaranteeing that competition will result in value appropriation; (3) there is a measure of scarcity, which we call minimum value, with the feature that competition implies a firm surely appropriates value if and only if the firm's minimum value is positive; and (4) if an agent is to appropriate value, a particular structure of competition is required. In summary, a firm's ability to appropriate some or all of the value it creates is determined by the features of the value creation process somehow interacting with competition among firms (Saloner et al., 2001).

Value is relative to competition. Delivering a better trade-off between benefits and sacrifices in a product or service, i.e. offering better value than competition, will help a company to create sustainable competitive advantages (Eggert and Ulaga, 2002). Real value creation-and long-term growth and profitability-occurs when companies develop a continuous stream of products and services that offer unique and compelling benefits to a chosen set of customers. This means that to maintain industry leadership, a company must establish a sustainable process of value creation (Hill and Jones, 1998).

What then becomes critical are the alternative responses to competition undertaken by different firms, some of which, given the nature of the business environment, are more likely to succeed than others.

In the emerging information economy, the most successful responses to competition focus on two areas: (1) innovation that drives down the cost of products and services 
while increasing their quality and variety, and (2) building a deeper understanding of changing customer needs within increasingly specific market segments. Responses that are rooted in a win/lose framework, such as taking a share from existing competitors in a zero-sum game, gaining power over customers (for example, by locking them into a proprietary computer operating system), or seeking to become the low-cost producer without simultaneously driving for world-class quality, are extremely dangerous (Slywotzky, 1996). Conversely, managers are more likely to stay focused on the higher return, win/win levers, if they aim not to beat the competition, per se, but to create more value than the competition-in other words, if they seek to achieve a "value-adding advantage." And by doing so, they are likely to be more successful than their competitors in the long run.

In order to gain this value-adding advantage or competitive advantage, Porter (1985) puts forward that "this advantage mainly depends on cost leadership, capability for differentiation, and focus". Besides, enterprises can be well developed if two major dominant strategies are properly integrated into business, and the noted strategies are "developing core competence" and "retrieving subtle strategic resources from outside world (so-called critical success factors, KSF)". The core competence of an organization may build up a product's competitive advantage on the market and creates a foundation for future product value (Quinn, 1999).

As a result, "value creation" can lead corporate competition to a fresh and more meaningful position. A company typically creates value for customers and superior returns for investors by producing goods or services that are better than their competitors by meeting a set of clearly defined needs for a specific set of customers. So, competition is a key variable in determining whether a product or service provides a differentiated benefit to the customer. However, the process of competition should never divert management from the primary task of creating those benefits by understanding and anticipating target customers' needs, excelling in product and process innovation, providing outstanding service, etc. (Davenport, 1992). Thus, we need to think of competition not as a goal, but as part of the business environment - a key element of the context in which a firm seeks to create value (Leonard-Barton, 1995).

\section{OTHER THEORIES AND PERSPECTIVES OF VALUE CREATION}

It is important to consider value creation as a key to collaborative supplieremployee-customer relationships. Management that is customer-oriented serves as a base for value creation. Additionally, employees need to be motivated and trained to create customer value. The section below highlights some of the literature concerning the above issues.

The value proposition is the program of products, services, ideas, and solutions that a business marketer offers to advance the performance goals of the customer. The 
value proposition is an important organizing force in the company because it directs all employees to focus on the customer requirements, and it provides the means for the company to orient the minds of its customers towards its offerings (Kaplan and Norton, 1992). Besides this, capability is also important in the process of value creation. The required capability, for any well-run organization's value to its customers and the basis of its valuation by shareholders, is to expand its resources continuously and effectively match these resources with high potential opportunities. This value-creation process is, in turn, built on the capabilities and motivation of the company's employees. Market-driven firms place high priority on customer-linking capabilities and closely align product decisions-as well as delivery, handling, service, and the value-chain activities-with the customer's operations (Brandenburger and Nalebuff, 1996).

Employees must be satisfied with both the product and services that are provided prior to supplying those items to the customer. Employees, of course, achieve themselves with what they are going to propose the value of product or service to customers. Value was then naturally created during the process of the exchange (Kotler, 2003). Besides, employees are functioning as a team to contribute their own knowledge, distinctive skills, specialties, and so on to the team to achieve the marketing values. Every team player has played evenly in the team with proper workloads; value is then naturally built up eventually (Kanigel, 1997).

Experience shows that in a value based management (VBM) culture, people are empowered to make better decisions, discipline their behavior, and work together more effectively as a team. Since each person contributes, risks and shares in each aspect of the work and ownership of the task, VBM helps to unite each employee's self interest around the company's bottom-line and corporate values. Poor value management detracts organizations from achieving successful business goals. In order to sustain the value in a business for the long term, a strategic decision-maker needs to point out clearly the direction to be taken and the struggles that could manifest themselves (Kelso and Adler, 1958).

Companies can transmit fundamental value perspectives and belief systems to its employees through a token, a ceremony, or a legend. Of course, companies must establish a working environment of mutual trust in order for employees to be expected to create value within the organization. A restrictive environment, which discourages individual initiative has been found to damage or even destroy the foundation of mutual links between the employees and the organization, which could even lead to a worse outcome of destroying the links to customers (Ouchi, 1981).

In addition, employees with limited knowledge tend to be disadvantaged in being able to create related benefits to customers. An inadequate knowledge base among its employees results in limited competencies for an organization, causing it to be 
ineffective in approaching the challenge of value creation (Lambert, 2004). Another factor limiting an organization's ability to provide value to customers is the arrogant and conceited attitudes, which may be present within the organization (Brandenburger and Nalebuff, 1996). Therefore, in order to avoid being replaced, a company must have the knowledge and capability to recognize the creation of business value, and this knowledge must be better than its rival's (Prahalad and Hamel, 1990). Distinctive skills may also be seen as equivalent to core competencies and refers to those skills and processes that are at the core of the company's value creating processes. Such skills differentiate one company from another in the same way that unique resources may also differentiate companies from each other. Distinctive skills are one factor that enables one company to out-perform another in the same market environment (Drucker, 2003).

Training is a learning process whereby people acquire capabilities to aid in the achievement of organizational goals. The ability to translate learning and training into job performance undoubtedly enhances competitiveness. Personal rewards or benefits must be relatively competitive and different, and should be based on performance to enhance the retention of employees (Mathis and Jackson, 2003). One key organizational value that affects employee retention is trust. One study of more than 600 employees found trust and organizational values as factors that most influenced the intentions by employees to stay with their current job. A distrustful environment could easily hurt the relationship between employee and employer thereby impacting the value creation chain within the organization. Hence, operational considerations such as strategies, policies, performance measures, rewards, analysis tools, and cultures are maximized in combination with VBM. If employees identify deviations between the above measures and their personal recognition for individual input, then value management has failed within the organization (Mathis and Jackson, 2003). In addition, perspective in the future matters the particular perceptions of effectiveness to the customer as well as expertise of company (Prahalad and Hamel, 1990). Overall, a positive value-creation culture in an organization determines the amount of value created for customers (Davenport and Short, 1990).

Combining all of the factors discussed above, customer feedback is still the most important benchmark that indicates the success or failure of a value creation program since a satisfied or unsatisfied customer will determine the long-term sustainability of an organization. Customers require products that meet their needs and prompt services that must be perceived as better than the competitors. Customers' evaluation is based upon cost of product or service in effectively meeting their needs, prospective quality and performance, and innovation and evolution, which in summary forms the purchase experience for the product or service (Ghemawat, 2001). Bad service and attitude will result in unsatisfactory customer response that ultimately means no value was created during the encounter of the service activities (Fitzsimmons and Fitzsimons, 2004). 
Business marketing strategy should therefore be based on the assessment of the company, competitor, and customer. A successful strategy focuses on identifying those opportunities in which the firm can deliver superior value to customers based on its distinctive competencies. From this perspective, marketing can be best understood as the process of defining, developing, and delivering value. By understanding customer needs, marketing managers can define value from the customer's perspective and convert that information into requirements for creating value within their organization. In turn, a firm's capabilities and skills determine the degree to which the company can meet these requirements and provide greater value than its competitors (Hamel, 1991).

According to Naumann (2000), delivering good customer value has many important quantifiable results. Good value leads to higher customer loyalty and retention. Good value leads to higher market share. Good value leads to reduced operating costs. Good value leads to more positive attitudes among both customers and employees. These improved performance measures then lead to improved profitability and better stock market performance. The relationship among these concepts is demonstrated in the model, The Value Payoff.

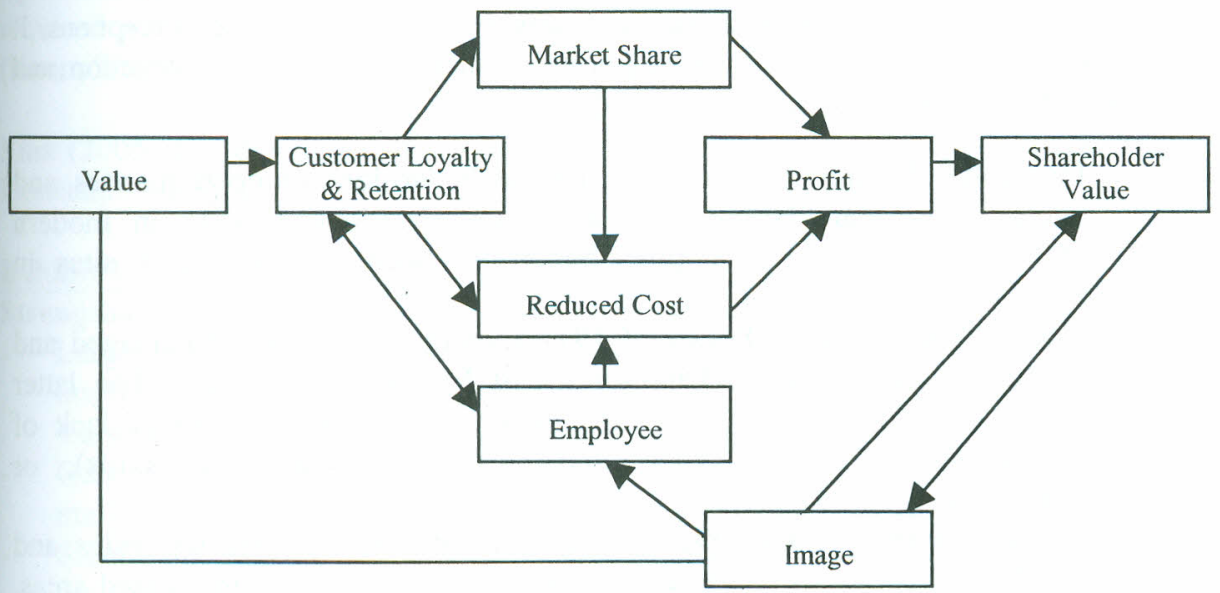

Figure 1: The Value Payoff

\section{MARBLE SECTOR IN NORTH-WEST FRONTIER PROVINCE}

NWFP produces about $98 \%$ of the country's total marble production. The province has about 160 million tons of marble reserves. The number of leases is 280 in NWFP and 8 in the FATA region. While there are a total of 300 processing units in the region ${ }^{2}$.

2 2002, 'Sectoral Brief: Marble Sector', Small and Medium Enterprise Development Authority, Government of Pakistan 
Farooqi (2004) reports that North-West Frontier Province (NWFP) and Federally Administered Tribal Area (FATA) have 158 million tons (98\%) of the country's total marble reserves. Zahra (2004) says that Pakistan only exports raw marble and in 2004, it accounted for US \$ 6.21 million in foreign exchange earnings that was approximately $0.38 \%$ of international marble exports. Some of the leading importers from Pakistan include USA, which imported $62 \%$ by value of Pakistan's marble in 2004.

The customers for dimensional stone and marble tiles can be classified into upper, upper middle and middle classes. According to usage the segments can also be classified as households, offices and buildings. The use of marble can be for external and internal facing, flooring, stairs, structural works, special works and others. The target market for marble can be divided into two groups; the domestic market and the international market (Khan, 2004).

The mineral sector in general suffers from lack of investment in machinery, skills, processes and updated market information resulting in poor efficiencies and sub-standard products. This is more visible in the marble sub-sector where primitive methods lead to large wastage, smaller size blocks, and poor quality material. The (traditional) private sector has shown little interest in moving up the value- addition chain, has no or a very poor knowledge of the international market needs and customer's value perceptions. It has relied on low cost (in some cases primitive) methods of marble extraction and processing. Some other sectoral issues pointed out are;

i) Generally, the mining industry is small scale, working on open quarries, and spread over many sites. It is also inefficient and lacking in modern technology, except for copper being produced at two major sites in Balochistan.

ii) The National Mineral Policy of 1995 requires mining to be managed and controlled by Provincial Directorates of Mines and Minerals. The latter have not been successful in carrying out their role because of lack of resources, whether financial, human (trained manpower, skills), or managerial.

iii) Finally, there is a perception about inconsistency in policies, rules and regulations, which is aggravated by poor law and order in the leased areas. (Working Draft, Planning Commission, Government of Pakistan, 2005)

Wastage rate in the marble industry is at an alarming $70 \%$. Pakistan is losing 40 million dollars yearly on marble and granite exports (Farooqi, 2004).

According to Mining and Quarrying Sector Profile (2003) there are three major clusters of processing units namely at Buner, Mohmand Agency and Peshawar. The province has white, black, green, pink, gray, yellow and brown varieties of marble of which all except pink are found in Buner. The second richest area in terms of reserves is Mohmand Agency, which suffers particularly from law and order 
problems. Buner and Mohmand Agency are followed by Chitral, Swat, Mardan, Kohat, Swabi, Waziristan, Bajaur, Parachinar and Nowshera in terms of marble reserves. Of these areas Chitral is particularly marred by problems such as snowfall in the Lowari Top area, huge distance from the market and lack of proper roads and transportation facilities especially bridges over the local river that can bear the load of heavy trucks carrying marble.

In the marble-processing sector the industry suffers from acute shortage of quality production suitable for export and lacks information about international markets and customer demands. Very few units have the modern machinery capable of processing dimensional stone according to international standards. Most of the processing units are equipped with local version of the cutting machinery with little or no calibration, high electricity consumption and low quality production. Marble products of these units have variation in tile thickness as high as 1 to $2 \mathrm{~mm}$ and are chipped at the edges. International standards allow variation in thickness up to 0.5 $\mathrm{mm}$ for tiles. Uneven raw blocks are contributing to high processing loss because of the material structure, cracks in the blocks and the inability to extract large sheets from these blocks resulting in poor value of the product. Another factor involved is the lack of skills among the processing workers who have not been provided with required training on cutting techniques even in plants having imported machinery (Khan, 2004).

Riaz (2005) has developed the following SWOT Analysis for the marble sector in Pakistan.

\section{Exhibit 1}

\section{Strengths:}

Large deposits of superior quality marble in the country

Variety of types and colors

General accessibility to major marble deposits

Significant number of mining and processing units

Hard working and low-cost mining labor

Traditional regional trading pockets

Culturally accustomed informal trading houses

\section{Weaknesses:}

- Inappropriate regulatory environment

- Distrust, apathy and control orientation of regulators

- Uncertainty of policy and fear of the unknown

- Inadequate infrastructure, critically low on mines

- Low investment and pathetic capitalization

Low mining skills and technology

- Non-existent supply chain and weak processing base

Lack of product awareness and quality appreciation

- Poor marketing effort and trade support 


\begin{tabular}{|c|c|}
\hline $\begin{array}{l}\text { Opportunities: } \\
\text { - } \text { Large and established world markets } \\
\text { - Comparative closeness in } \\
\text { international market } \\
\text { - New trends of marble usage } \\
\text { internationally } \\
\text { Rehabilitation in Afghanistan and } \\
\text { Central Asian Republics } \\
\text { - Increased strategic focus on sectoral } \\
\text { exports } \\
\text { Improved awareness and availability } \\
\text { of local stone } \\
\text { Proposed changes in regulatory } \\
\text { environment for private sector facilitation } \\
\text { Institutionalization of support efforts } \\
\text { by the government } \\
\text { Quality standards implementation } \\
\text { Improved handling/transportation } \\
\text { technologies }\end{array}$ & 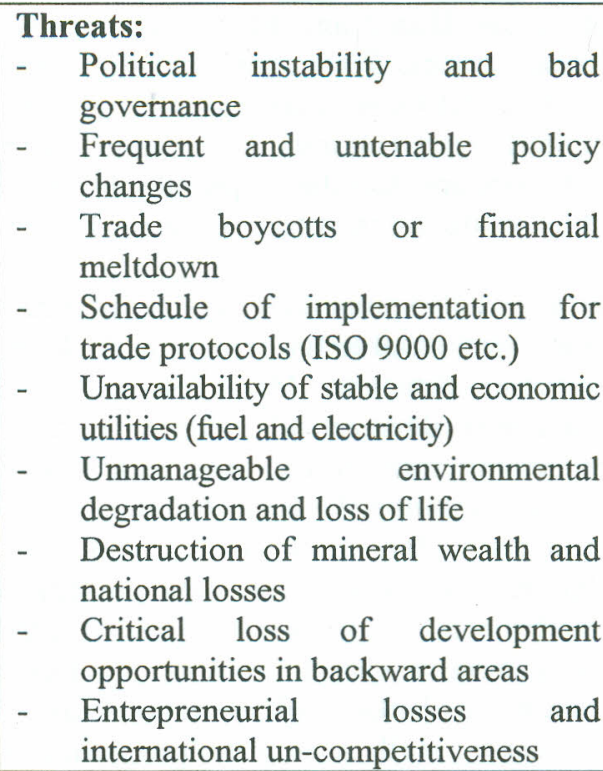 \\
\hline
\end{tabular}

\section{THE DRIVERS AND BARRIERS TO CUSTOMER VALUE CREATION}

Enterprises sometimes choose not to focus on value creation and instead unintentionally make decisions that systematically decrease the long-term value of their businesses. It is perhaps because managers tend to define their organizations' interests narrowly. This narrow view is powerfully reinforced by financial accounting systems that are well adapted to the industrial economy, but are inadequate in the information economy. The accounting and finance conventions of the industrial age are effective at valuing tangible assets, but they largely ignore the value of harder-to-quantify assets like employee satisfaction, learning, R\&D effectiveness, customer loyalty, etc. (Mathis and Jackson, 2003). In the information age, intangible assets are far more important than the tangible assets that traditional accounting systems were designed to measure.

If management defines the organization's self-interest (and consequently its goals) too narrowly - for example, to maximize this year's or this quarter's reported earnings - it will view that interest as being at odds with the interests of customers and employees. Given that perspective, in the short term every dollar spent on employee training, for instance, is a dollar of lost profit. Every additional dollar earned from a customer, even if it comes at the cost of poor service or price gouging, improves this quarter's results (Kotler, 2003).

Alternatively, if managers define their company's interests broadly enough to include the interests of customers and employees, an equally powerful spiral of value 
creation can occur. Highly motivated, well-trained, properly rewarded employees deliver outstanding service, while effective R\&D investments lead to products that enjoy a significant value-adding advantage and generate higher margins. Satisfied, loyal customers (and new customers responding to word-of-mouth referrals) drive revenue growth and profitability for investors (Kotler, 2003).

One way to build an understanding of these dynamics is to identify the key capabilities, resources, and relationships that are the basic ingredients of value creation for a particular firm, and to think of those ingredients as assets that either grow or diminish over time, depending upon how they are managed. It is then useful to map a company's key assets by building a "value creation net" focused on employees, processes, customers, and investors (see Figure 2). In building the value creation net, managers should decide which assets are the most important drivers of the company's value-creation system. For example, employee learning and job satisfaction are two assets that could be tracked on the part of the employee in the value creation net.

\section{Reinvestment in Employees}

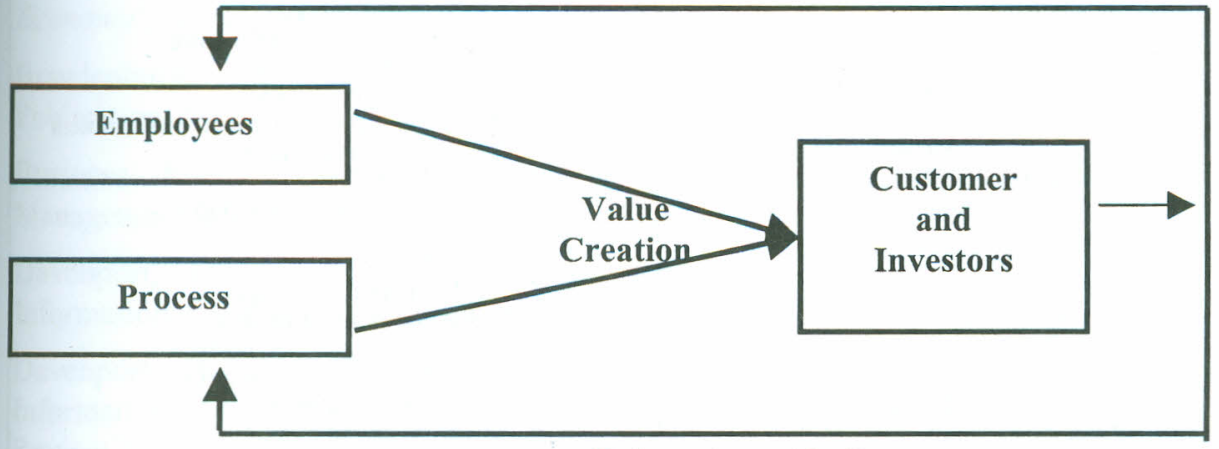

Reinvestment in Process

Figure 2: VALUE CREATION NET

As managers identify the strategic assets that belong in each value creation net, they also must articulate the relationships among those assets. By tracing the dynamics through which customer, employee, and process assets accumulate, interact, and ultimately drive profitable growth, a company will be well on its way to managing the fundamentals of value creation and avoiding the pitfalls of management by following a set of narrow financial measures.

In Figure 2, the corporate value can be seen as being created from three major sources within the cycle, as noted above - from employees, from process, and from customers and investors through reinvestment. The target companies for the intended research study are located in Peshawar (the capital of the province) and Buner, which has a large presence of SMEs involved in marble mining and processing. The value 
for investors can be considered in combination with the value for customers in this framework, which forms the basis for business growth and profitable returns. The profitable return is then significantly reinvested back into both the employees and process assets of the company, but the cycle could be either positive or negative, depending on the responses from the market.

As has been mentioned in the previous discussion, employees and processes contribute significantly to enterprise value creation. From the literature review a preliminary assumption is that there are a number of drivers and barriers to value creation from the dimension of employees and process. These are shown in Figure 3. However, which of these are relevant to the marble sector in Pakistan and what others need to be identified is an issue that needs to be further explored.

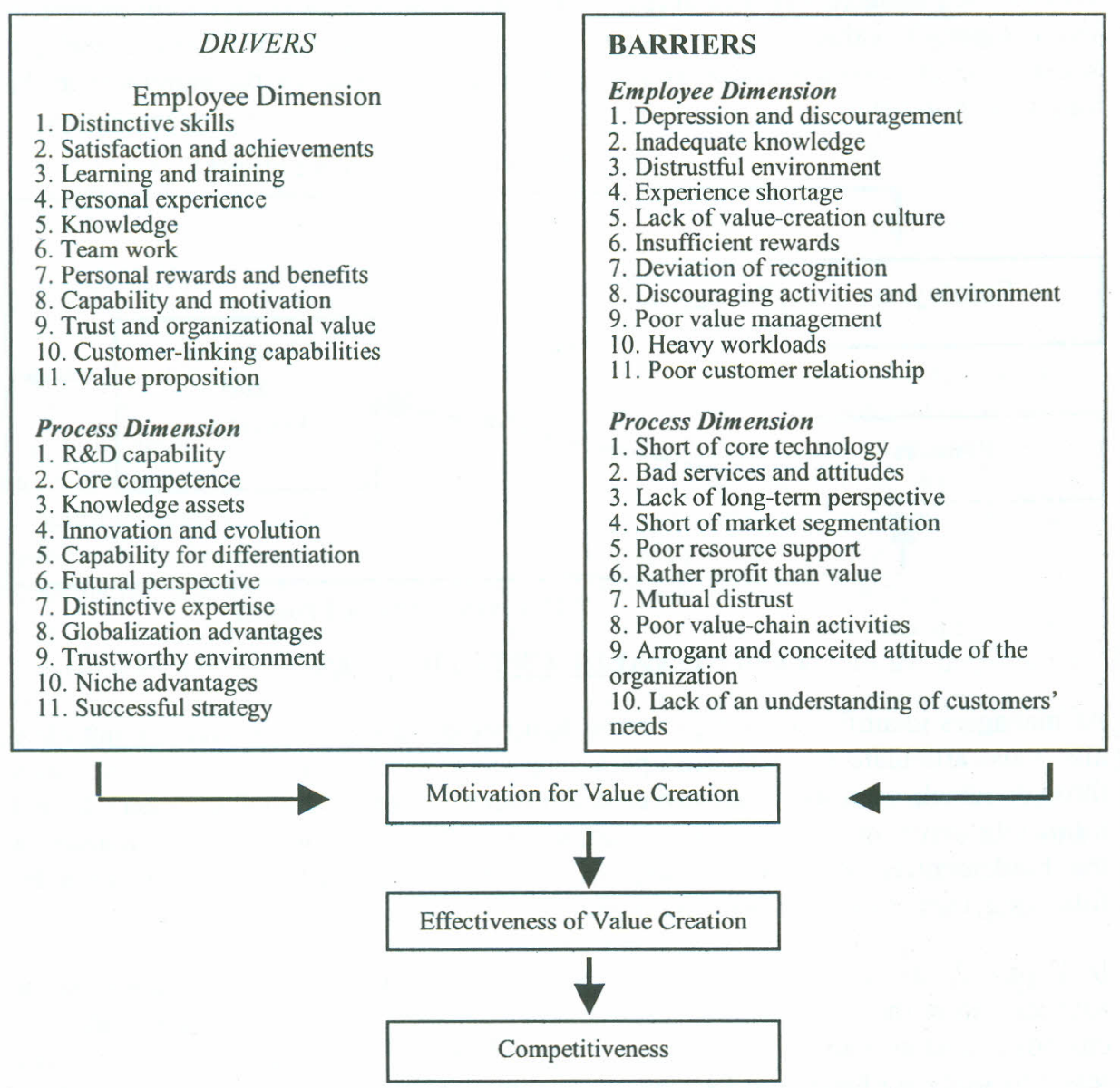

Figure 3: Factors of Value Creation 


\section{CONCLUDING REMARKS:}

Based on the issues and perspectives highlighted in this paper, it is evident that in order to be more competitive, SMEs in the marble sector will have to place greater emphasis on customer value creation. While value itself has been approached from various perspectives, creating value for the customer is inextricably linked to employees and processes. The review of literature identifies a number of drivers and barriers to customer value creation from the dimension of employees and processes. However, research is needed to find out which of these have greater relevance to Pakistan's marble sector. The author intends to carry out further research to develop a Value Model for a marble enterprise demonstrating the relationship between value and the key drivers and barriers. Further, by using the Value Model, the author intends to demonstrate a quantifiable relationship between customer value (resulting from employees and processes), and the key drivers and barriers.

\section{REFERENCES}

Batjargal, B.: 2000, 'The Dynamics of Entrepreneurial Networks in a Transitional Economy', Working Paper, No. 350 (William Davidson Institute, Ann Arbor, USA).

Brandenburger, M. A. and J. Nalebuff: 1996, Co-opetition (Currency Doubleday Publication, New York).

Business Plan, Entrepreneurship Development Centre: 2005, (Institute of Management Sciences, Peshawar, PAKISTAN).

Davenport, H. T.: 1992, Process Innovation: Reengineering Work through Information Technology (Harvard Business School Press, Boston).

Davenport, H. T. and J. E. Short: 1990, _The New Industrial Engineering: Information Technology and Business Process Redesign_, Sloan Management Review 31, 11-27.

Drucker, F.P.: 2003,Managing in the Next Society (St. Martin's Pressing).

Eggert, A. and W. Ulaga: 2002, 'Customer-Perceived Value: A Substitute for Satisfaction in Business Markets?', Journal of Business and Industrial Marketing 17(2-3), 107-118.

Expert Advisory Cell, Government of Pakistan: 2003, 'Mining and Quarrying Sector Profile', 281.

Farooqi, M.: 2004, 'Pakistan losing $\$ 40 \mathrm{~m}$ on Marble and Granite exports annually', (Business News - The Nation on Web, http://nation.com.pk/daily/oct2004/30/bnews7.php, October 2004).

Fitzsimmons, A. J. and J. M. Fitzsimmons: 2004, Service Management (McGrawHill). 
Ghemawat, P.: 2001, Strategy and Business Landscape: Core Concept (Prentice Hall).

Hamel, G.: 1991, _Competition for and Inter-partner Learning within International Strategic Alliances_, Strategic Management Journal 12, 83-103.

Hill, C. and G. R. Jones: 1998, Strategy Management Theory: Integrated Approach, McGraw-Hill.

Iqbal, A.: 2005, 'Situational Analysis of Marble Processing Industry in Peshawar', (Institute of Management Sciences, Peshawar, PAKISTAN).

Kanigel, R.: 1997, The One Best Way (Viking Penguin).

Kaplan, S. R. and P. D. Norton: 1992, _The Balanced Scorecard: Measures that Drive Performance, Harvard Business Review 70, 71-79.

Kelso, O. L. and J. M. Adler: 1958, The Capitalist Manifesto (Random House).

Khan, B. M.: 2004, 'Marble Sector in N.W.F.P, Peshawar', 5 - 6

Kotler, P.: 2003, Marketing Insights from A to Z (John Wiley and Sons, New York).

Lambert, S.: 2004, 'ACT Budget 2004-05 Community Briefing Report' (Department of Treasury, Australian Capital Territory Government, mimeo).

Leonard-Barton, D.: 1995, Wellsprings of Knowledge: Building and Sustaining the Sources of Innovation (Harvard Business School Press, Boston).

MacDonald, G. and M. D. Ryall: 2001, 'Lower Bounds on Equilibrium Payoffs in Superadditive Value Games', Research Working Paper (University of Rochester).

Mathis, L. R. and H. J. Jackson: 2003, Human Resource Management (Thomson Publishing).

Mishler, E. G.: 1986, Research Interviewing: Context and Narrative (Harvard University Press, Cambridge).

Naumann, E.: 2000, 'Creating Customer Value: The Linkage between value, customer satisfaction, customer loyalty and profitability’, A White Paper.

Niazi, K.: 2005, 'Training of Trainers in Entrepreneurship: Concept Paper', (Institute of Management Sciences, Peshawar, PAKISTAN).

Nonaka, I. and H. Takeuchi: 1995, The Knowledge-Creating Company: How Japanese Companies Create the Dynamics of Innovation (Oxford University Press, New York).

Ouchi, G. W.: 1981, Theory Z (Addison Wesley, MA).

Planning Commission, Government of Pakistan: 2005, 'Working Draft on Medium Term Development Framework 2005-10' 
Porter, M. E. 1985, Competitive Advantage: Creating and Sustaining Superior Performance (Free Press).

Prahalad, C. K. and G. Hamel: 1990, _The Core Competence of the Corporation_, Harvard Business Review 68, 79-91.

Quinn, J. B.: 1999,_Strategic Outsourcing: Leveraging Knowledge Capabilities_, Sloan Management Review 40, 9-22.

Riaz, M.: 2005, 'Critical Analysis of Marble Sector in N.W.F.P', (Investment Opportunities in North West Frontier Province, Pearl Continental Hotel, Peshawar, PAKISTAN).

Saloner, G., A. Shepard and J. Podolny: 2001, Strategic Management (John Wiley \& Sons, New York).

Saunders, T.: 2003, 'The Research Process Onion', Research Proposal: Anterior Cruciate Ligament: Anatomy, Symptoms and Reconstruction.

Sectoral Brief: 2004, 'Marble and Granite', (Small and Medium Enterprise Development Authority, Government of Pakistan).

Slywotzky, J. A.: 1996, Value Migration: How to Think Several Moves Ahead of the Competition (Harvard Business School Press, Boston).

SME Overview: 2005, 'Consultative Workshop on SME Policy Development', (Pearl Continental Hotel, Peshawar, PAKISTAN).

Zahra, N.: 2004, 'Marble in Our Province', (Dawn Review, September 2 - 9, 2004, $15-16)$.

To go from good to great requires transcending the curse of competence. It requires the discipline to say, "Just because we are good at it - just because we're making money and generating growth - doesn't necessarily mean we can become the best at it." The good-to-great companies understood that doing what you are good at will only make you good; focusing solely on what you can potentially do better than any other organization is the only path to greatness.

Jim Collins 